\title{
PENGARUH MEDIA PEMBELAJARAN INTERAKTIF PIVOT OFF LINE TERHADAP MINAT BELAJAR SISWA DI SMA NEGERI 1 PINANGSORI
}

\author{
Ainun Mardiyah Lubis \\ Pendidikan Fisika, FKIP, Universitas Muhammadiyah Tapanuli Selatan, \\ e-mail:ainun.mardiyah@um-tapsel.ac.id.
}

\begin{abstract}
This research is a quasi-experimental study aimed to determine the effect of Pivot off line interactive learning media on students' interest in learning physics at Pinangsori 1 High School and to know the effect of Pivot off line interactive learning media on student physics learning outcomes on business (work) and kinetic energy material in Pinangsori 1 High School. The population in this study were all students of class X MIA SMA Negeri 1 Pinangsori, which consisted of 4 classes (130 students). The sample of this study was determined by random cluster sampling, amounting to 30 people. The research instrument is learning interest. The average value of the final ability (Post-test) in the experimental class after the implementation of learning methods assisted by Pivot Animator software increased. The experimental class post-test results are (for $x_{\max }=95, x_{\min }=75$, dan $\bar{x}=84,3$ ), while the control class post-test results are (for $x_{\max }=80, x_{\min }=60$, dan $\bar{x}=73,1$ ). The initial results of the questionnaire students' interest in learning physics in the experimental class were (for $x_{\max }=90, x_{\min }$ $=60$, dan $\bar{x}=79,3$ ), while in the control class were (for $x_{\max }=80, x_{\min }=50$, dan $\bar{x}=69,1$ ) it can be concluded that Pivot off line interactive learning media on students' learning interest in Pinangsori 1 High School.
\end{abstract}

Keywords: Learning Media; Pivot Off Line; Interest to learn

\begin{abstract}
Abstrak
Penelitian ini merupakan penelitian quasi eksperimen bertujuan untuk mengetahui pengaruh media pembelajaran interaktif Pivot off line terhadap minat belajar fisika siswa di SMA Negeri 1 Pinangsori dan untuk mengatahui pengaruh media pembelajaran interaktif Pivot off line terhadap hasil belajarfisika siswa pada materihubungan usaha (kerja) dan energi kinetik di SMA Negeri 1 Pinangsori. Populasi dalam penelitian ini adalah seluruh siswa kelas X MIA SMA Negeri 1 Pinangsori yang terdiri dari 4 kelas (130 siswa). Sampel penelitian ini ditentukan dengan cara cluster random sampling yaitu berjumlah 30 orang. Instrumen penelitian ini adalah minat belajar. Nilai ratarata kemampuan akhir (Post-test) pada kelas eksperimen setelah diberlakukan metode pembelajaran berbantuan software Pivot Animator lebih meningkat. Hasil post-test kelas eksperimen adalah (untuk $x_{\max }=95, x_{\min }=75$, dan $\bar{x}=84,3$ ), sedangkan hasil post-test kelas kontrol adalah (untuk $x_{\max }=80$, $x_{\min }=60$, dan $\left.\bar{x}=73,1\right)$. Hasil awal angket minat belajar fisika siswa pada kelas eksperimen adalah (untuk $x_{\max }=90, x_{\min }=60$, dan $\bar{x}=79,3$ ), sedangkan pada kelas kontrol adalah (untuk $x_{\max }=80, x_{\min }$ $=50$, dan $\bar{x}=69,1)$ maka dapat disimpulkan media pembelajaran interaktif pivot off line terhadap minat belajar siswa di SMA Negeri 1 Pinangsori.
\end{abstract}

Kata Kunci: Media Pembelajaran; Pivot Off Line; Minat Belajar

\section{PENDAHULUAN}

Proses belajar mengajar di sekolah adalah salah satu upaya interaksi antara guru, siswa dan lingkungannya yang bertujuan untuk mencapai perubahan-perubahan tingkah laku intelektual, moral maupun sosial. Proses pembelajaran yang terjadi di kelas ditentukan oleh beberapa komponen pembelajaran, antara lain: tujuan pembelajaran, materi/bahan ajar, 
metode dan media, evaluasi, peserta didik, dan pengajar (Toto Ruhimat, dkk., 2011:47)

Pada proses belajar mengajar kehadiran media mempunyai arti yang cukup penting. Karena dalam kegiatan tersebut ketidak jelasan bahan yang disampaikan dapat dibantu dengan menghadirkan media sebagai perantara. Kerumitan bahan yang akan disampaikan kepada peserta didik dapat disederhanakan dengan bantuan media. Media dapat mewakili apa yang kurang mampu guru ucapkan melalui kata-kata atau kalimat tertentu. Bahkan keabstrakan bahan dapat dikonkretkan dengan kehadiran media.

Kehadiran media pembelajaran sebagai alat bantu guru dalam penyampain bahan ajar khususnya pada pelajaran fisika masih terabaikan, hal ini dapat terlihat berdasarkan hasil Pra Penelitian yang telah dilaksanakan peneliti di SMA Negeri 1 Pinangsori. Pemusatan perhatian siswa hanya tertuju pada media pembelajaran yang simple yaitu papan tulis dan buku paket. Penyampaian bahan ajar hanya dibantu dengan menuliskan materi pada papan tulis dan penyediaan buku peket.

Media pembelajaran Interaktif Off Line merupakan salah satu jenis media pembelajaran yang tidak terkoneksi dengan internet, hanya beroperasi dengan komputer stand alone (Rob Philips, dalam Sutirman 2013:10). Proses pembelajaran akan berjalan lancar apabila tidak adanya kendala dalam komponen pembelajaran. Media ini memungkinkan untuk mengatasi salah satu kendala dalam komponen pembelajaran tersebut, proses pembelajaran dapat terus berjalan lancar tanpa harus terusik oleh koneksi jaringan internet.

Menurut Crow \& Crow (dalam Djali, 2008:121) mengatakan bahwa "minat berhubungan dengan gaya gerak yang mendorong seseorang untuk menghadapi atau berurusan dengan orang, benda, kegiatan, pengalaman yang dirangsang oleh kegiatan itu sendiri. Belajar adalah serangkaian kegiatan jiwa raga untuk memperoleh suatu perubahan tingkah laku sebagai hasil dari pengalaman individu dalam interaksi dengan lingkungannya yang menyangkut kognitif, afektif, dan psikomotorik (Djamarah, 2011:13).

Menanggapi masalah diatas tentang masih kurangnya minat belajar fisika siswa maka peneliti berusaha untuk meningkatkan penggunaan media pembelajaran dengan penggunaan software animation sederhana. Software ini akan mensimulasikan gambar bergerak dengan aplikasi pada materi fisika yang membantu siswa lebih terfokus, tidak jenuh dan bosan serta mempermudah pemahaman siswa (Supardi, 2015:71-81).

\section{METODE}

Adapun metode yang digunakan adalah metode deskriptif dan metode eksperimen. Metode deskriptif digunakan untuk melihat gambaran tentang kedua variabel. Sedangkan metode eksperimen digunakan untuk melihat pengaruh di antara kedua variabel penelitian. Populasi merupakan keseluruhan objek penelitian. Adapun yang menjadi populasi dalam penelitian adalah semua siswa kelas X MIA SMA Negeri 1 Pinangsori yang terbagi dalam 4 kelas dengan jumlah siswa 130 orang. Sampel adalah bagian dari yang mewakili sebagian dari populasi. Teknik pengambilan sampel yang digunakan adalah cluster random sampling dimana setiap kelas memiliki kesempatan yang sama untuk menjadi sampel penelitian. Adapun sampel yang diambil adalah kelas X MIA 2 berjumlah 30 siswa.

Penelitian ini didesain dalam model one group pretest posttest design dengan melaksanakan eksperimen hanya pada satu kelas saja tanpa ada kelas pembanding. Hal ini sesuai dengan yang dinyatakan oleh Suharsimi Arikunto (2010) bahwa one group pretest posttest design yaitu eksperimen yang dilaksanakan pada satu kelompok saja tanpa kelompok pembanding. Kelas sampel diberikan pretest yang bertujuan untuk melihat kemampuan awal siswa. Setelah dikenai perlakuan menggunakan model pembelajaran discovery learnig berbantuan media software dalam pembelajaran, kelas sampel diberikan posttest untuk melihat kemampuan akhir yang dimiliki siswa. 


\section{HASIL DAN PEMBAHASAN \\ Hasil Penelitian}

Nilai rata-rata kemampuan akhir (Post-test) pada kelas eksperimen setelah diberlakukan metode pembelajaran berbantuan software Pivot Animator lebih meningkat dibandingkan dengan kelas kontrol yang tidak mendapat perlakuan. Untuk kelas eksperimen $(\bar{X}=84,3)$ sedangkan pada kelas kontrol $(\bar{X}=73,1)$ terlihat pada Gambar 1 .

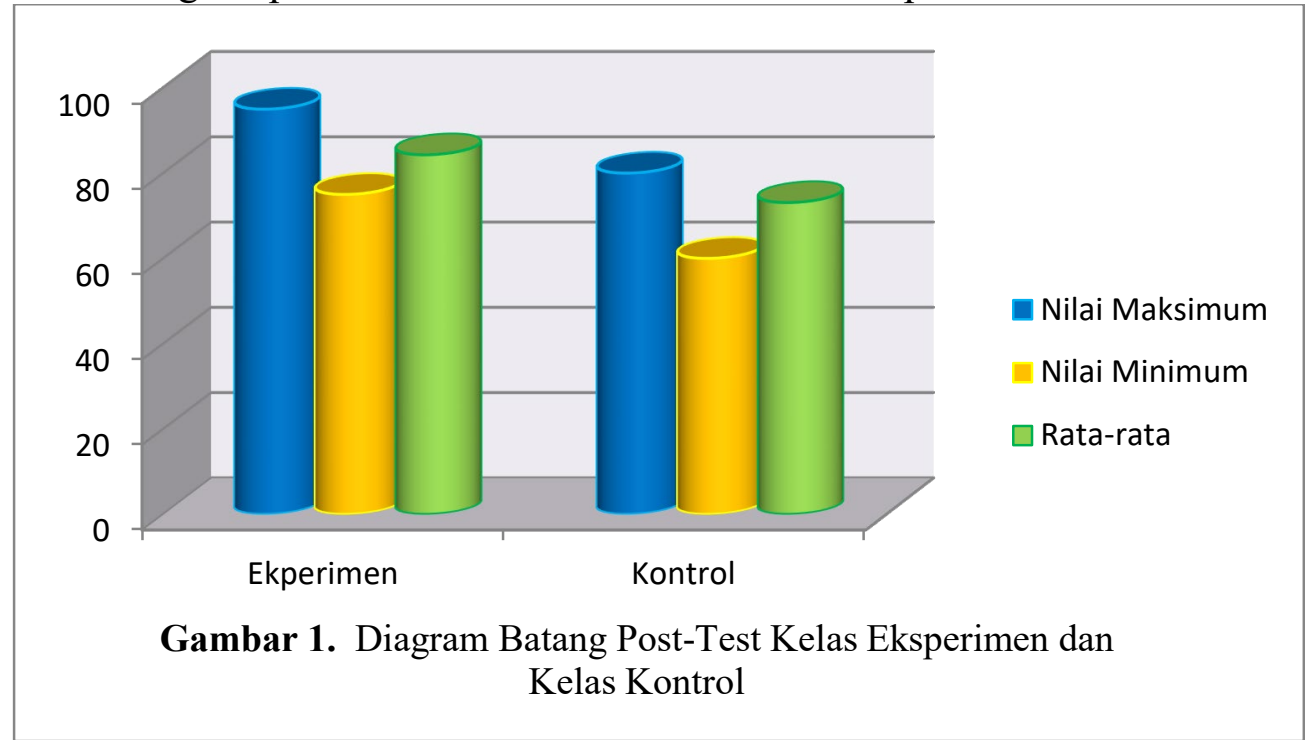

Hasil post-test kelas eksperimen adalah (untuk $x_{\max }=95, x_{\min }=75$, dan $\bar{x}=84,3$ ), sedangkan hasil post-test kelas kontrol adalah (untuk $x_{\max }=80, x_{\min }=60$, dan $\bar{x}=73,1$ ).

Data yang diperoleh dalam penelitian ini adalah data hasil angket minat belajar fisika siswa dari materi Hubungan Usaha (Kerja) dan Energi Kinetik dimulai hingga materi ini berakhir. Minat belajar siswa terhadap pelajaran fisika pada kelas eksperimen dapat dikualifikasikan sebagai berikut untuk kualifikasi kurang sebanyak 3 orang (sekitar 10\%), cukup sebanyak 23 orang (sekitar 76,7\%), dan baik sebanyak 4 orang (sekitar 13,3\%), sedangkan pada kelas kontrol minat belajar siswa terhadap pelajaran fisika dikualifikasikan sebagai berikut untuk kualifikasi kurang sebanyak 28 orang (sekitar 93,3\%) dan cukup sebanyak 2 orang (sekitar 6,67\%) seperti gambar 2.

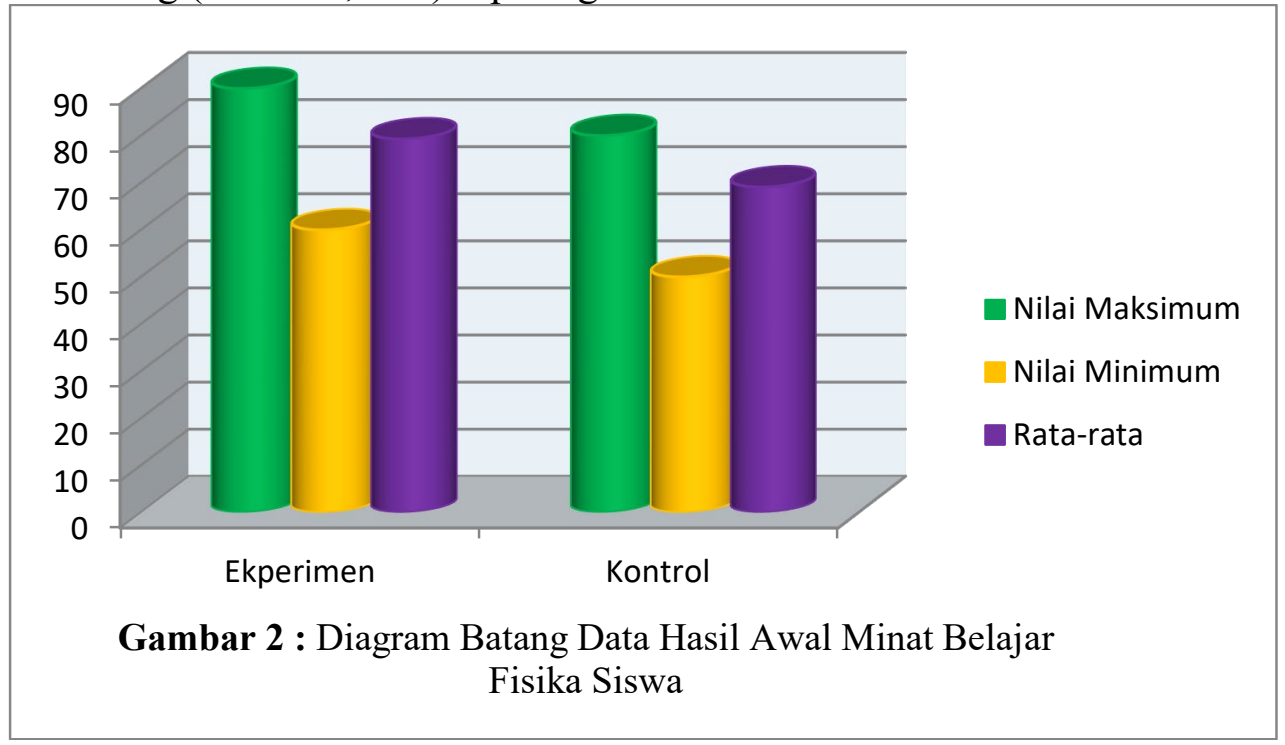


Hasil awal angket minat belajar fisika siswa pada kelas eksperimen adalah (untuk $x_{\max }$ $=90, x_{\min }=60$, dan $\bar{x}=79,3$ ), sedangkan pada kelas kontrol adalah (untuk $x_{\max }=80, x_{\min }=$ 50, dan $\bar{x}=69,1)$.

Minat belajar siswa terhadap pelajaran fisika pada kelas eksperimen dapat dikualifikasikan sebagai berikut untuk kualifikasi cukup sebanyak 1 orang (sekitar 3,3\%), baik sebanyak 23 orang (sekitar 76,7\%), dan sangat baik sebanyak 6 orang (sekitar 20\%), sedangkan pada kelas kontrol minat belajar siswa terhadap pelajaran fisika dikualifikasikan sebagai berikut untuk kualifikasi kurang sebanyak 6 orang (sekitar 20\%) dan cukup sebanyak 20 orang (sekitar 66,7\%), dan baik sebanyak 4 orang (sekitar 13,3\%).

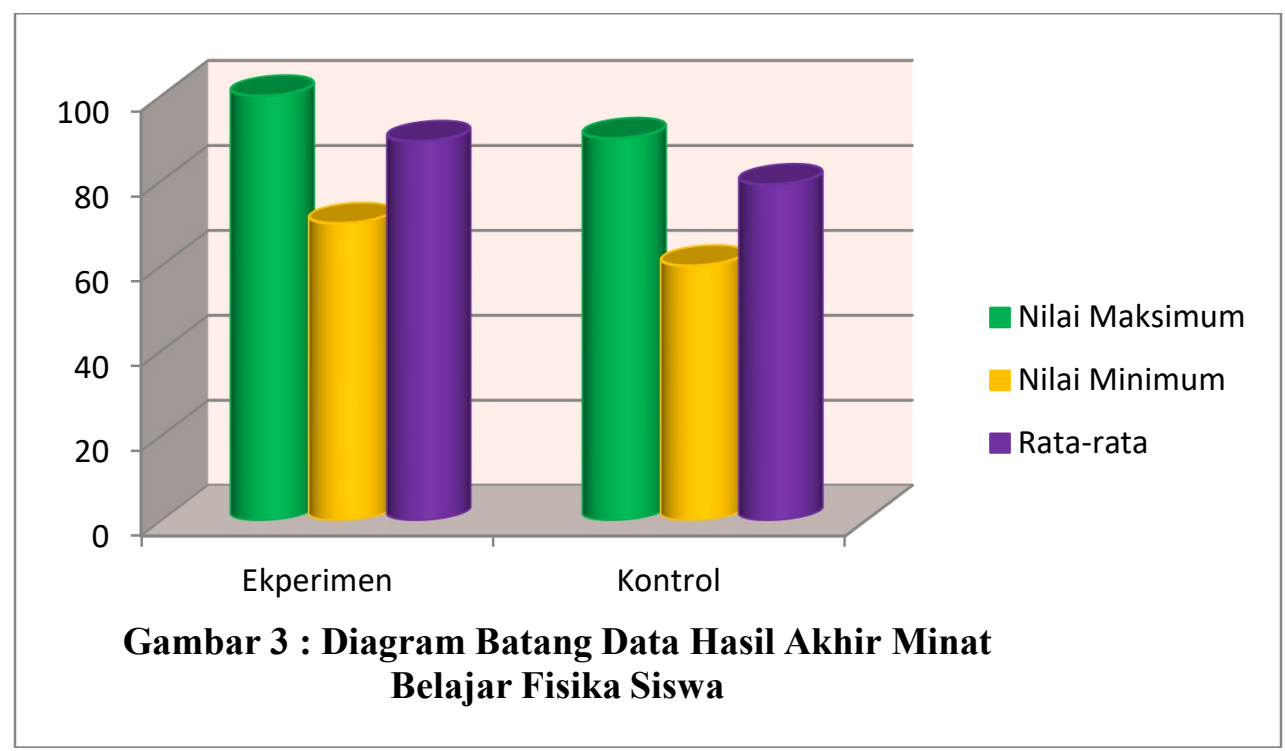

Dapat disimpulkan bahwa hasil awal angket minat belajar fisika siswa pada kelas eksperimen adalah (untuk $x_{\max }=90, x_{\min }=60$, dan $\bar{x}=79,3$ ), sedangkan pada kelas kontrol adalah (untuk $x_{\max }=80, x_{\min }=50$, dan $\bar{x}=69,1$ ).

\section{Pembahasan}

Pada hipotesis pertama ada perbaikan minat belajar fisika siswa melalui penerapan media pembelajaran interaktif Pivot off line di kelas X MIA SMA Negeri 1 Pinangsori. Hal ini didukung dengan angket minat belajar fisika siswa yang telah di analisis. Perbaikan minat belajar fisika siswa lebih baik setelah mendapat perlakuan penerapan media pembelajaran, dengan rincian hanya $3,3 \%$ kriteria cukup pada minat belajar fisika dan $t_{\text {hitung }}>t_{\text {tabel }}=7,42>2,00$.

Dan pada hipotesis kedua ada perbaikan hasil belajar fisika siswa melalui penerapan media pembelajaran interaktif Pivot Off line di kelas X SMA Negeri 1 Pinangsori. Hasil belajar di kelas eksperimen lebih baik dari pada kelas kontrol, ini terbukti dengan hasil post-tes yang telah di uji. Hasilnya menunjukkan bahwa nilai-nilai kelas eksperimen lebih tinggi dari pada kelas kontrol, tingkat kelulusan hasil belajar fisika di kelas eksperimen juga lebih unggul dari pada kelas kontrol. Hal ini tidak terlepas dari kelas eksperimen yang mendapat penerapan media pembelajaran interaktif Pivot off line dengan rincian $t_{\text {hitung }}>\mathrm{t}_{\text {tabel }}=7,18>2,00$.

\section{KESIMPULAN}

Berdasarkan hasil penelitian Terdapat pengaruh media pembelajaran terhadap minat belajar fisika siswa pada materi Hubungan Usaha (Kerja) dan Energi Kinetik dengan menggunakan metode pembelajaran berbasis komputer berupa software animation Pivot Animator di kelas X MIA SMA Negeri 1 Pinangsori. Dibuktikan dengan hasil perhitungan 
uji-t diperoleh $\mathrm{t}_{\text {hitung }}=7,42$ pada taraf $\boldsymbol{\alpha}=0,05 \mathrm{dan} \mathrm{dk}=30+30-2=58$ dengan $\mathrm{t}_{\text {tabel }}=2,00$. Sehingga diperoleh $t_{\text {hitung }}>\mathrm{t}_{\text {tabel }}$ atau 7,42 $>2,00$, dapat dikatakan $\mathrm{H}_{0}$ ditolak dan $\mathrm{H}_{\mathrm{a}}$ diterima.

Terdapat pengaruh media pembelajaran terhadap hasil belajar fisika siswa pada materi Hubungan Usaha (Kerja) dan Energi Kinetik dengan menggunakan metode pembelajaran berbasis komputer berupa software animation Pivot Animator di kelas X MIA SMA Negeri 1 Pinangsori. Dibuktikan dengan hasil perhitungan uji-t dengan membedakan nilai rata-rata post-test antara kedua kelas sampel. Hasil perhitungan diperoleh $t_{\text {hitung }}=7,18$ pada taraf $\alpha=$ 0,05 dan $\mathrm{dk}=30+30-2=58$ dengan $t_{\text {tabel }}=2,00$. Sehingga diperoleh $t_{\text {hitung }}>t_{\text {tabel }}$ atau 7,18 $>2,00$, dapat dikatakan $\mathrm{H}_{\mathrm{a}}$ diterima dan $\mathrm{H}_{0}$ ditolak.

\section{DAFTAR PUSTAKA}

Arikunto, Suharsimi. 2010. Prosedur Penelitian Suatu Pendekatan Praktik. Jakarta:Rineka Cipta.

Arikunto, S, Suhardjono dan Supardi. 2014. Penelitian Tindakan Kelas. Jakarta: Bumi Aksara.

Djamarah, Syaiful Bahri. 2011. Psikologi Belajar Edisi II. Jakarta: PT Rineka Cipta.

Resnick, Halliday. 1985. Fisika. Bandung: PT Gelora Pratama Aksara.

Ruhimat, Toto dkk. 2011. Kurikulum dan Pembelajaran. Jakarta: Rajawali Press.

Sugiyono. 2011. Metode Penelitian Kuantitatif Kualitatif dan $R \& D$. Bandung: Alfabeta.

Sutirman, ( 2013). Media \& Model-model Pembelajaran Inovatif.Yogyalarta: Graha Ilmu 